Beata Karpińska-Musiał

Uniwersytet Gdański

Instytut Anglistyki i Amerykanistyki

\title{
KRK DLA SZKOLNICTWA WYŻSZEGO W POLSCE JAKO OKAZJA DO PRZEKSZTALCEŃ W SFERZE KOMPETENCJI W GLOTTODY- DAKTYCE. KOMUNIKAT Z WSTĘPNYCH BADAŃ NA TEMAT FORMUŁOWANIA I WALIDACJI EFEKTÓW KSZTAŁCENIA W RAMACH REFORMY SZKOLNICTWA WYŻSZEGO
}

\author{
The National Qualification Framework for higher education in Poland as \\ an opportunity to reframe the competencies of academic teachers \\ of foreign languages. Introductory research on the reception of the \\ formulation of learning outcomes and their validation within the \\ reform of tertiary education
}

This article presents a theoretical discussion, supported by empirical research, about the attitudes of university teachers of foreign language in Poland towards the implementation of the National Qualification Framework for Higher Education. The opinions on the topic were collected by a questionnaire, conducted in March 2012, among representatives of 17 Polish universities. The research aimed to investigate whether institutional and administrative change connected with the reform of higher education in Poland is in any way contributing to reframing of competencies, or to the development of new competencies in foreign language teachers and researchers. The internationalization of tertiary education and demands for orientation to the job market, widely discussed in literature and public debate recently, are irreversibly connected with globalization and the Bologna process. It is important to raise the question how this affects the generic and specific competencies of teacher trainers and educators. The research results revealed that academics are highly sceptical about the assumptions and effects of the implementation of the NQF. It is the author's intention to diagnose the reasons for this in the context of seeing the NQF as creating new space for modified and redefined skills, which are indispensable in the new educational reality. 


\section{Wprowadzenie}

Artykuł prezentuje postawy nauczycieli akademickich w Polsce wobec wdrażania Krajowych Ram Kwalifikacji dla szkolnictwa wyższego na studiach filologicznych oraz formułowania przy tej okazji celów i walidacji efektów kształcenia. Postawy te wyłaniają się z badania przeprowadzonego na początku 2012 roku wśród pracowników dydaktycznych i naukowo-dydaktycznych wydziałów filologicznych i neofilologicznych 17-tu uniwersytetów klasycznych w Polsce. Dotyczyło ono opinii respondentów na temat podpisanej 5 kwietnia, a wchodzącej w życie 1 października 2012 nowelizacji ustawy z 18 marca 2011 r. dotyczącej prawa o szkolnictwie wyższym. W artykule postawione zostanie pytanie, czy zdaniem polskiej kadry akademickiej powstają w obliczu zmiany prawnoadministracyjnej okoliczności sprzyjające rozwojowi nowych kompetencji w dydaktyce językowej, czy też dotychczasowe kompetencje raczej zostają przeformułowane? Umasowienie i urynkowienie edukacji, mimo kontrowersji, jakie wzbudzają na forach dyskusji akademickich oraz w literaturze przedmiotowej, stanowią zjawiska nieodłącznie związane z globalizacją (Mohamedbhai 2012). W ich obliczu należy zastanowić się, jakim modyfikacjom bądź też jakiemu stopniowi anihilacji podlegają lub podlegać powinny uznawane dotąd za wiodące kompetencje przedmiotowe (specific) oraz ogólne (generic) w glottodydaktyce. Tłem rozważań będą tutaj definicyjne ujęcia kompetencji oraz kwalifikacji nauczycieli w ujęciu różnych autorów. Materiał empiryczny, przedstawiający fragmenty opinii środowiska neofilologów w Polsce na temat KRK, osadzony jest zatem w kontekście przede wszystkim kompetencji związanych z koniecznością ustosunkowania się do zmian związanych z reformą szkolnictwa wyższego. Wypowiedzi respondentów dają obraz niesłychanie dużej kontestacji wobec wdrażanej reformą zmiany instytucjonalnej oraz jej efektów. Celem autorki jest zatem analiza tej kontestacji w kontekście rekonstrukcji i transformacji konkretnych umiejętności, i próba odpowiedzi na pytanie czy KRK stanowią zamach na dotychczasową jakość kształcenia językowego, czy może kreują przestrzeń do realizacji nowych, innych niż dotąd kompetencji?

\section{Klasyfikacje kompetencji nauczyciela języków obcych - przegląd typologii w literaturze przedmiotu}

\section{Kompetencje ogólne nauczycieli}

Klasyfikacja kompetencji nauczycieli stanowi już niezwykle obszerny dział literatury przedmiotu. Typologie są tak liczne, podobnie jak i rodzaje wiedzy, kwalifi- 
kacji, umiejętności oraz postaw osobowościowych, jakie przypisuje się „typowi idealnemu" nauczyciela, że przytaczanie ich tutaj wykracza poza możliwości objętościowe tego tekstu. Podobnie rzecz się ma z listą autorów definiujących pojęcie kompetencji. Zajmują się nim badawczo, zarówno z ogólno pedagogicznej, jak i glottodydaktycznej oraz międzykulturowej perspektywy $\mathrm{m}$. in. Kacprzak, Pfeiffer, Banach, Stasiak, Kwieciński, Śliwerski, Okoń, Pituła, Myczko, Wilczyńska, Zawadzka-Bartnik, Siek-Piskozub, Michońska-Stadnik, Bandura, Byram, Komorowska, Speck, Dudzikowa, Stach, Radwan, Dylak, Jaroszewska, Werbińska, Kurcz i wielu innych. Wszyscy badacze analizują pojęcie kompetencji ze strony trzech kluczowych wytycznych: wiedzy, postaw oraz umiejętności. Opisują w swych badaniach to, co Arends ujęła w następujących słowach:

Od nauczycieli XXI wieku będzie się żądać władania zasobem wiedzy: przedmiotowej, pedagogicznej, społecznej i z zakresu kultury; będą oni musieli stać się refleksyjnymi twórcami i profesjonalistami (Arends1994).

Powyższym cytatem Banach (2005) rozpoczyna jedną ze swoich ewaluacyjnych (a zarazem prognostycznych, bo obejmujących planowane działania do roku 2020) analiz wprowadzanej w Polsce już od roku 1989 reformy systemu edukacji oraz miejsca nauczyciela w tym procesie. Przy tej okazji wymienia on funkcje i zadania nauczyciela, które w wielu aspektach musiały ulec przeorientowaniu w stosunku do wcześniejszego systemu edukacji, i które można przypisać ogólnym standardom kompetencji zawodowych nauczycieli w odróżnieniu od kompetencji wymaganych od glottodydaktyków. Kilka słów kluczowych, tak jak wymienia je Banach (2005), pozwala na stworzenie lepszego tła dla zrozumienia wytyczanych na nowo kompetencji i zadań nauczyciela XXI wieku: są to „szkoła-edukacja a rynek pracy”, „rozumieć świat-kierować sobą”, „kształcenie ustawiczne”. Każda z tych sfer wytycza nowe zadania w zakresie trzech głównych rodzajów funkcji nauczyciela: kierowniczej, interakcyjnej i organizacyjnej (Arends 1994). Należą tu np. gotowość do przygotowania młodzieży do wejścia na rynek pracy i takie kierowanie ich nauką, by byli zdolni do adaptacji i dalszego samodoskonalenia, bycie autonomicznym w poszukiwaniu i tworzeniu nowej wiedzy, otwarcie na „inność” w procesie negocjacji potrzeb różnych ludzi (empatia), umiejętność organizacji pracy i dobrej współpracy w grupie zarówno innych nauczycieli jak i uczniów itp. U podłoża powyższych kategorii cech leżą przede wszystkim określone kierunki przemian społeczno-kulturowych, które Banach formułuje następująco:

- koncentracja na kulturze ogólnej oraz realizacja wspólnych wartości cywilizacji europejskiej: prawa i swobody człowieka, prawomocność demokratyczna, równość szans jednostek, „kultura pokoju”, posza- 
nowanie innych ludzi, respektowanie mniejszości, myślenie racjonalne, ochrona ekosystemu, odpowiedzialność jednostkowa;

- rozwój przydatności do zatrudnienia i zdolności do efektywności ekonomicznej;

- kształtowanie społeczeństwa informacyjnego i strategia „uczenia się przez całe życie" (Banach 2005).

Podaje on też przykład kategoryzacji różnych kompetencji nauczycielskich, które zaliczyć można do tzw. kompetencji ogólnych. Są to: kompetencja poznawcza, językowa, wartościująco-komunikacyjna, interpersonalna, kulturowa, życiowego doradztwa, praktyczno-moralna i organizacyjno-techniczna. Ponadto, wielorakie aspekty kompetencji kluczowych, czyli związanych z otwartością, innowacyjnością, elastycznością, humanizacją, ustawicznością i wysokim poziomem kultury osobistej oraz umiejętności psychologicznych, rzucają nauczycielowi wyzwanie wymagające nie tylko wiedzy, ale przede wszystkim „krytycznego i alternatywnego myślenia oraz odwagi w postępowaniu, (...) wiążą się z zasadami naukowej i pedagogiczno-psychologicznej teorii organizacji pracy, oznaczają również określony poziom stosunków międzyludzkich" (Banach 2005:14).

W raporcie OECD ${ }^{1}$ na temat polityki edukacyjnej w Polsce z 1995 roku czytamy też, że w całym morzu koncepcji i orientacji dotyczących pedagogicznych kwalifikacji nauczycieli w okresie transformacji i po nim należy skupić się na trzech celach, z których pierwszym i najistotniejszym jest orientowanie edukacji nauczycielskiej na kształtowanie właśnie osobowości i postaw nauczycieli. Od zmiany tych postaw zależy sukces proponowanych transformacji. Drugim elementem są kompetencje kluczowe, natomiast trzecim dopiero odpowiedni dobór treści i form nauczania.

\section{Kompetencje a kwalifikacje - w kierunku utylitarnego przygotowania zawodowego nauczycieli języków obcych na tle kompetencji ogólnych}

Przykłady typologizacji można mnożyć, a zestawienie kompetencji językowej z komunikacyjną kieruje nas w stronę czysto zawodowych kompetencji nauczycieli języka obcego. W tym miejscu jednak pojawia się problem dwojakiego rodzaju: braku możliwości poczynienia ostrego podziału pomiędzy kompetencjami ogólnymi a szczegółowymi oraz mylącej granicy pomiędzy pojęciem kompetencji a kwalifikacji.

W nawiązaniu do pierwszego problemu, okazuje się, że w obliczu tak mnogiej liczby kategoryzacji umiejętności nauczycieli trudno o wyrazisty

${ }^{1}$ Raport na temat polityki edukacyjnej w Polsce, OECD. 1995. W-wa: WSiP. 
podział między kompetencjami ogólnymi a przedmiotowymi. W zawodzie nauczyciela jego cechy osobowości i predyspozycje psychologiczne stanowią automatycznie jego umiejętność zawodową. Nabyta wiedza na temat metodologii i faz rozwoju ucznia, etapów akwizycji języka itp. stanowią tylko uzupełnienie kompetencji specjalistycznych oraz dydaktycznych. Goźlińska i Szlosek (1997) do tychże dwóch kategorii dodają od razu też psychologicznq, związaną z motywowaniem uczniów i odpowiednią diagnozą ich możliwości - a to już zaliczyć można do kompetencji ogólnych (generic) (interpersonal sensitivity, influencing others ). ${ }^{2}$ Również Stach (za: Kacprzak 2006: 49) pisze o kompetencjach osobowościowych (a wśród nich moralnych, interpretacyjnych, komunikacyjnych) jako o kompetencjach zawodowych nauczyciela. Michalski (za: Kacprzak 2006: 49), także w kontekście kompetencji zawodowych wymienia m.in. wychowawcze (jaki jest mój wysiłek w tworzeniu humanizacji oddziaływań na uczniów?) oraz komunikacyjne (po co spotykamy się w szkole?). Tę ostatnią kompetencję można wręcz rozpatrywać w kategoriach inkontrologii pedagogicznej, czyli filozofii spotkania, jaka znajduje realizację w działaniach szkolnych i wykracza znacznie poza kompetencje czysto metodyczne lub instrumentalne (Śliwerski 2010). Dylak (za: Kacprzak 2006: 48) wymienia jeszcze podział na kompetencje bazowe, konieczne i pożqdane - kategoryzację wskazującą prawie wyłącznie na umiejętności intelektualne, zmysłowe, związane z talentami lub nietypowymi cechami osobowości oraz samoorganizacji. W ramach kompetencji koniecznych, Dylak wprowadza jeszcze podział na kompetencje: interpretacyjnq (gotowość do refleksji na bazie wiedzy przedmiotowej i umiejętności pedagogicznych), autokreacyjnq (samowiedza i świadomość relacji z innymi) oraz realizacyjnq (pozwalającą na realizację wytyczonych zadań w instytucji).

Wobec więc takiego zatarcia się granicy pomiędzy niegdyś bardziej oczywistymi kategoriami, warto przyjrzeć się rozróżnieniu pomiędzy „kompetencjami” a „kwalifikacjami”, aby uzyskać bardziej klarowny obraz tego, co wymagane jest od współczesnego nauczyciela. Według Kacprzaka (2006: 47), kwalifikacje mają charakter formalnego przygotowania do wykonywania zawodu, czyli możliwości spełniania wszelkich wymagań stawianych przed pełnioną funkcją (np. ukończenie odpowiedniej szkoły). Czytamy też za Szlosek, że samo słowo kwalifikacje pochodzi „z języka łacińskiego qualitas i mniej więcej oznacza jakość. Z kwalifikacją wiąże się więc ściśle czynność kwalifikowania, czyli określania jakości" (za: Kacprzak 2006: 42). Według Oskara Langego natomiast, kwalifikacje to „umiejętność, zręczność i wprawa, jak również wysiłek cielesny i umysłowy, wymagane przy wykonywaniu prac przez poszczególne zawody" (Lange 1965: 72).

\footnotetext{
${ }^{2}$ http://www.ucas.com/seps/criteria/genericcompetencies, DW 2.11.2012.
} 
Kwalifikacje tak rozumiane uważane są za element składowy kompetencji, które „odnoszą się do umiejętności wykorzystywania posiadanych kwalifikacji” (Kacprzak 2006: 47). Kompetencja jest więc pojęciem szerszym i bliższa jest zestawowi cech, które uznalibyśmy za ogólne, a nie przedmiotowe. Definiowana jest między innymi jako „zdolność i gotowość do wykonywania zadań na oczekiwanym poziomie (Jenkins za: Czerepaniak-Walczak 1995), lub „osiągnięcie określonych standardów w obrębie danej praktyki” (Carr za: Dylak 1995:36). Nieostrość pojęć jest jednak i tak widoczna, zwłaszcza w pedeutologii, która wprowadza podział na kwalifikacje zawodowe i ogólne. Pedeutolodzy definiują kwalifikacje ogólne jako podstawę kwalifikacji zawodowych, tj. jako „wiadomości i umiejętności sytuacyjne nauczyciela $w$ gronie ludzi wszechstronnie wykształconych, dysponujących wiedzą i kulturą o zasięgu znacznie wykraczającym poza wyuczoną specjalność zawodową" (Kupisiewicz 2005). Oba pojęcia wchodzą w każdym razie w zakres tzw. kwalifikacji zawodowych.

Cechą, która być może najbardziej odróżnia kompetencję od kwalifikacji jest jej wymieniana przez Stacha „generatywność i transferowalność, czyli możność przenoszenia się na inne dziedziny aktywności jednostki i tworzenia się nowych kompetencji". Ta właściwość koreluje z wymienianymi także przez tego samego autora składowymi kompetencjami warsztatu nauczyciela: kompetencją transpozycyjnq, krytycznq i organizacyjnq (Stach 2002: 19 za: Kacprzak 2006: 50). Do tych trzech rodzajów kompetencji, podobnie jak i do podziału Dylaka na kompetencje realizacyjnq, autokreacyjnq, interpretacyjnq oraz ich wspomnianych właściwości generatywności oraz transferowalności powrócę w akapicie dotyczącym rozbudowywania lub rekonstrukcji kompetencji w obliczu KRK.

\section{Uwarunkowania procesów walidacji osiągnięć oraz uznawania efektów kształcenia w edukacji formalnej, poza formalnej i nie- formalnej}

Najbardziej odczuwalny dla akademickiej kadry uniwersyteckiej rezultat obecnej reformy szkolnictwa wyższego, jakim jest wprowadzenie Krajowych Ram Kwalifikacji, wiąże się bezpośrednio z uznawaniem efektów kształcenia zdobywanego przed przystąpieniem do studiów oraz walidacją osiągnięć w edukacji formalnej, nieformalnej oraz poza formalnej. KRK narzuciły poszczególnym wydziałom polskich uniwersytetów obowiązek (ale tym samym dały okazję) do zweryfikowania programów studiów oraz sprecyzowania sylabusów poszczególnych przedmiotów według określonych wytycznych. Szczególne kontrowersje wzbudzała konieczność sformułowania ujednoliconych ogólnych oraz kierunkowych efektów kształcenia dla poszczególnych 
cykli dydaktycznych. Zadanie to, jakkolwiek wywołało negatywne i krytyczne reakcje tych, którzy musieli je wykonać, stanowi konsekwencję procesu przekształcania systemu szkolnictwa wyższego w duchu tendencji neoliberalnych. Jest konsekwencją umasowienia oraz urynkowienia edukacji wyższej. Demokratyzacja edukacji jest tendencją powszechną i globalną, w różnych formach i wymiarze, ale jednak dotykającą całego globalizującego się świata. Procesy te pociągają za sobą pewne konsekwencje, takie jak obniżenie poziomu kształcenia oraz konieczność standaryzacji pewnych procedur instytucjonalnych. Sformułowanie oraz ujednolicenie efektów kształcenia dla określonych kierunków jest jedną z takich konsekwencji, która w założeniach ma pomagać w uzyskiwaniu stopni naukowych lub dyplomów przez kandydatów o coraz bardziej złożonej i barwnej historii edukacji. Wielokulturowość społeczeństw, nawet tych najbardziej dotąd homogenicznych (do których Polska się zalicza), staje się faktem. Można więc spodziewać się, że zarówno ze względu na interkulturowe migracje ludności, jak i zróżnicowanie doświadczeń szkolno-edukacyjnych, młodzi kandydaci na studentów będą przychodzić z bardzo nierównym poziomem wiedzy i kompetencji. W krajach Europy Zachodniej podejmowane są już od jakiegoś czasu sformalizowane działania mające na celu weryfikację oraz uznanie efektów kształcenia uzyskanego nie tylko na innych uczelniach, ale także w edukacji poza-formalnej (kursy, szkolenia) lub nieformalnej (drogą autoedukacji). Sytuacja w Polsce scharakteryzowana została przez Tomasza Saryusz-Wolskiego, dyrektora Centrum Kształcenia Międzynarodowego Politechniki Łódzkiej, podczas jednej z cyklicznych konferencji REA odbywającej się w 2011 roku w Gdańsku. ${ }^{3}$ Jego zdaniem uzyskiwanie kompetencji (z mierzalnymi efektami kształcenia) następuje de facto w kolejności następującej (a nie jest to kolejność typowa dla edukacji polskiej): 1) edukacja nieformalna, 2) poza-formalna, 3) formalna. Celem więc współczesnych posunięć administracyjnych powinno być zatem rozwiązanie problemu, jak osiągnąć równowagę między tymi formami kształcenia.

3 Zdaniem Saryusza-Wolskiego polski system edukacji z perspektywy kształcenia ustawicznego cechują następujące rysy:

- $\quad$ proces kształcenia to głównie edukacja formalna i ewentualnie poza-formalna;

- dominuje kolekcjonowanie świadectw, dyplomów i certyfikatów - bez koncentracji na efektach;

- istnieje brak wyraźnego rozdziału pomiędzy „procesem nauczania” a „procesem weryfikacji efektów uczenia się" (ogólnie nacisk kładziony jest na nauczanie a nie na uczenie się);

- $\quad$ kwalifikacje nadawane są w kolejności: 1) edukacja formalna $\rightarrow$ 2) pozaformalna $\rightarrow$ 2) nieformalna. 


\section{Rekonstrukcja kompetencji wobec nowopowstałych okoliczności - zagrożenie czy szansa?}

W takich okolicznościach konieczne jest poddanie weryfikacji niektórych z licznie wymienianych wyżej kategorii kompetencji dydaktycznych, przede wszystkim ogólnych, celem dokonania ich rekonstrukcji w nowej, zmieniającej się rzeczywistości edukacyjnej. Męczkowska-Christiansen (2002) pisząc o kompetencjach rekonstrukcyjnych ucznia określa je między innymi jako umiejętność dokonywania transpozycji wcześniejszych doświadczeń edukacyjnych na wiedzę zdobywaną współcześnie, i tworzenie w ten sposób wiedzy o nowej jakości i znaczeniu. Zadaniem współczesnego nauczyciela jest zatem stwarzanie uczącym się takich warunków dydaktycznych i psychologicznych, które umożliwiać będą przetwarzanie wiedzy poprzez autoedukację połączoną z wiedzą zdobywaną z zewnątrz. Zadanie to wymaga od nauczającego umiejętności elastycznego transponowania określonych elementów wiedzy podawczej na zróżnicowane doświadczenia i wiedzę wyjściową wychowanków. Wydaje się więc, że i on/ona powinni posiadać owe rekonstrukcyjne kompetencje, odpowiadające wymienianej pośród kompetencji ogólnych wrażliwości interpersonalnej (interpersonal sensitivity). Podobnego rodzaju kompetencja określana jest przez Dylaka jako kompetencja autokreacyjna, której podstawą jest „świadomość relacji z innymi podmiotami, zdobywana podczas zorganizowanej obserwacji samego siebie" (Dylak 1995: 38-41).

Kompetencje tego typu wydają się posiadać cechy wspomniane wyżej w tym tekście: transferowalność i generatywność. Kompetencja jako pojęcie szersze od kwalifikacji różni się od nich między innymi tym, że ma możliwość przenoszenia się na inne obszary działań edukacyjnych: np. z merytorycznych na organizacyjne, $z$ organizacyjnych na społeczne, ze społecznych na naukowe. Ich generatywność natomiast może polegać na kreatywnym wykorzystaniu różnego rodzaju kwalifikacji oraz kompetencji w zupełnie nowych okolicznościach i wobec nowych zadań. Można sądzić, że Stach ma tutaj na myśli potencjalną możliwość swoistego „pączkowania” kompetencji na potrzeby nowych zadań, lub inaczej, możliwość manipulowania poszczególnymi kwalifikacjami przedmiotowymi oraz innymi rodzajami kompetencji na rzecz doraźnego zadania lub sytuacji. Cechy te jawią się jako znacząco istotne wobec konieczności sprostania zmianie instytucjonalnej i paradygmatycznej, z jaką obecnie zmagają się uniwersytety, $w$ tym także respondenci przedstawianego niżej badania. Warto więc zwrócić ponownie uwagę na dwa rodzaje klasyfikacji kompetencji, przytaczane w tym tekście już wcześniej, których charakterystyka wydaje się szczególnie odpowiadająca wyzwaniom, jakie stawia 
przed nauczycielami reforma oraz KRK. Mowa o typologiach Dylaka na kompetencje interpretacyjne, autokreacyjne oraz realizacyjne oraz opisane przez Stach kompetencje transpozycyjne, krytyczne i organizacyjne. Dlaczego one właśnie mogą aspirować do roli kluczowych?

Kompetencje interpretacyjne obejmują według Dylaka trzy aspekty: aspekt wartości pedagogicznych, wiedzy przedmiotowej, wiedzy i umiejętności pedagogicznych. Sprawiają, że „nauczyciel przygotowany jest do refleksji i wyciągania wniosków". Autorefleksja, uważana za podstawę skutecznej dydaktyki (Ryan 2007), wydaje się być niezbędna w obliczu konieczności przetwarzania własnych warsztatów pracy dydaktycznej, do czego reforma mniej lub bardziej bezpośrednio nakłania. Jest też konieczna do wymaganej przez posunięcia instytucjonalne oceny formalizacji osiągnięć, nie tylko studentów, ale też kadry akademickiej. Kompetencje autokreacyjne opierają się na „samowiedzy, postawie badawczej i pytającej”, oraz „tworzeniu własnej sylwetki zawodowej". Niezależnie od preferencji lub antypatii wobec tego zjawiska, marketyzacja edukacji wprowadza mechanizmy rynkowe także w tę sferę. Działalność naukowa w pewnym sensie traci swój prywatny i zindywidualizowany charakter na rzecz działania wspólnotowego, kooperacyjnego, naznaczonego mechanizmami swoistej autoreklamy. Nauka ma się rozwijać zbiorowo w ramach projektów naukowych, wymagających szczegółowych opisów, enumeracji osiągnięć, planów, budżetów. Koncepcyjna strona badań staje się tylko jednym z elementów pracy naukowej akademików. Jej zaistnienie na rynku edukacyjnym, to zupełnie inna sfera jego działalności, która wymaga pewnej dozy autokreacji. Kompetencje realizacyjne natomiast rozpatrują każdą czynność nauczyciela w trzech wymiarach: „obiektu, na który jest skierowana, poziomu zorganizowania oraz ogólnego schematu działania". Docelowo, są to umiejętności pozwalające na skuteczną realizację zadań w instytucji. Jeśli do takowych należą konieczność napisania sylabusów czy też sformułowanie efektów kształcenia, realizacja takiej kompetencji zależy przede wszystkim od poziomu zorganizowania pracowników i zrozumienia przez nich celowości wytyczonych zadań.

Z kompetencjq realizacyjnq ściśle wiąże się typowana przez Stach kompetencja transpozycyjna. Pyta ona o to, „czy i jak jestem przygotowany do zmieniających się warunków, mając określone dyspozycje?” (Stach 2002:19). Zmieniające się warunki są dokładnie tym, co stało się codziennością rzeczywistości akademickiej i źródłem największych frustracji. Warto więc może sięgnąć po kolejną kompetencję z przytaczanego zestawu: krytycznq, która nakazuje zapytać, „co trzeba zmienić w wykonywanej pracy, co dopracować, jakimi drogami to osiągnąć?" Kwestionowanie rzeczywistości może w razie niejasności prowadzić do konstruktywnej zmiany w podejściu do zadań. Konieczność spro- 
stania wymogom KRK niewątpliwie zrodziła szereg wątpliwości i okazji do pytań na temat tego, co z dawnego status quo należy zostawić, a co zmienić (np. w programach studiów). Była więc okazją do rozwijania kompetencji krytycznej, nie tylko w kontekście kontestacji, ale także transformacji. Ostatnia ze wspomnianych przez Stach kompetencji: organizacyjna, pokrywa się z wcześniejszą realizacyjnq, dodatkowo zapytując o to, „jak określam sprawność organizacyjną swojej pracy?" Namysł nad tym aspektem miał także okazję nastąpić podczas formułowania efektów kształcenia według narzuconych kodów i symboli. Czynność teoretycznie jałowa, wymuszała jednak pewną konsekwencję i techniczne podejście do zagadnień teoretycznych. Jest to punkt najbardziej zagorzałej krytyki środowiska wobec KRK, gdyż humanistom trudno jest posługiwać się sztywnymi schematami wobec zjawisk opisujących ludzkie umiejętności, wiedzę i postawy. Jak okaże się za chwilę w badaniu, to dla postaw (umiejętności społecznych) najtrudniej było sprecyzować formułowane w niemal matematycznej formule efekty kształcenia filologicznego. Wydaje się bowiem, że trudno tu znaleźć bezpośrednie przełożenie. Ale może właśnie w tym momencie warto sięgnąć po wspominane kompetencje transpozycyjne i wykorzystać transferowalność posiadanych kompetencji?

\section{Badanie empiryczne: metoda, procedura i wyniki}

Opinie neofilologów na tematy związane z reformą oraz KRK zbadano anonimową ankietą online w lutym i marcu 2012. Uzyskany został zwrot w liczbie 188 respondentów. Przedstawione poniżej wybrane pytania i odpowiedzi stanowią tylko część całkowitej ankiety, która składała się z 20 pytań o kafeterii zamkniętej (poza metryczką), z możliwością dodawania komentarzy. Prezentowane tu pytania w ilości 12-tu pogrupowane zostały, ze względu na tematykę artykułu, na trzy bloki tematyczne. Pierwszy dotyczy bezpośrednio opinii o formułowaniu celów i efektów kształcenia wg KRK na studiach językowych oraz w stosunku do przedmiotów szczegółowych, jak również o przewidywanej ich realizacji w poszczególnych dziedzinach studiów neofilologicznych. Drugi blok dotyczy zagadnienia walidacji efektów kształcenia oraz akredytacji wcześniejszej edukacji w kontekście kształcenia ustawicznego. Natomiast trzeci blok to zaledwie dwa pytania ogólne, dotyczące postrzegania rozbieżności pomiędzy teorią a praktyką w glottodydaktyce w kontekście kompetencji nauczycieli. Badanie ma charakter triangulacji, gdyż łączy metodę ilościową z jakościową analizą wybranych wypowiedzi respondentów. Nie jest celem tego artykułu ocena czy są one uzasadnione, czy nie. Cel badania jest wyłącznie diagnostyczny i deskryptywny, oparty o metodę fenomenologiczną, i ma pokazać przeżyciowy charakter stosunku do zmiany, bez oceny jej wad lub zalet. 
Oto, co wyłania się z badania. Ponad połowa badanych $(52,1 \%)$ uważa, że wdrażanie KRK oraz reformy szkolnictwa wyższego „komplikuje proces dydaktyczny, zmuszając niejako do konsekwencji w precyzowaniu celów kształcenia oraz ich mierzenia po cyklu dydaktycznym", a podobny odsetek osób $(54,7 \%)$ formułowanie celów i efektów kształcenia wobec dotychczasowych programów studiów neofilologicznych uważa za „utrudnienie administracyjne i czasochłonne zadanie bez większego sensu merytorycznego”. Jednak dla prawie jednej czwartej $(24,4 \%)$ była to zarazem okazja do „weryfikacji własnych działań dydaktycznych oraz wzmożonej współpracy kadry akademickiej”. Tylko po mniej więcej 15\% respondentów (czyli po ok. 100 osób w kraju) uważa, że wdrażanie KRK niesie ze sobą szansę na kształtowanie kompetencji kluczowych u pracowników naukowych $(14,3 \%)$ lub ewentualnie studentów kształconych w nowym trybie $(15,4 \%)$. Zarazem dominująca większość $(61,1 \%)$ uznała, że proces formułowania celów i efektów wobec własnych przedmiotów „byłźródłem dużej irytacji przede wszystkim ze względu na brak czasu”, i tylko dla 22\% stanowił „interesujące wyzwanie mimo czasochłonności". Kolejne trzy pytania z tego bloku dotyczyły prognoz co do realizacji sformułowanych kolejnymi kategoriami (wiedzy, umiejętności i postaw) celów i efektów kształcenia w poszczególnych dziedzinach kształcenia neofilologicznego: językoznawczej, literaturoznawczej i kulturoznawczej. W każdym z tych przypadków zdecydowana większość uznawała zgodnie, że najtrudniej będzie realizować efekty kształcenia w zakresie kompetencji społecznych, czyli postaw, i to w przypadku każdej dziedziny kształcenia językowego. Najtrudniej dokonać tutaj przełożenia w ramach językoznawstwa (w tym dydaktyki języka obcego) - uważa tak prawie $60 \%$ badanych, ponad $43 \%$ uważa podobnie w kwestii przedmiotów literaturoznawczych, a stosunkowo najłatwiej wydaje się, że dokona się realizacja celów w zakresie kultury (za najtrudniejsze uważa to zadanie $34,5 \%$ ). I tak jest to najwyższy odsetek w ramach danego pytania, co oznacza, że i tak większość uznała realizację celów w kategorii postaw za najtrudniejszą w obrębie tej dziedziny.

Drugi blok pytań nawiązywał ogólniej do zagadnienia walidacji efektów kształcenia w kontekście reformy oraz zjawiska Lifelong Learning. Pytano o samą koncepcję i jej sensowność oraz znajomość wybranych terminów z zakresu kształcenia ustawicznego. I tak, dla dominującej większości (ok. 80\%) respondentów koncepcja walidacji efektów kształcenia jest albo „tworem czysto teoretycznym, „nowomową” bez znaczenia” (40\%), albo „formalnym terminem z rejestru procesu bolońskiego, nie wnoszącym wiele do praktycznej sfery dydaktyki" (40\%). Odpowiedzi te zawarte były w jednym pytaniu, w którym tylko dla 16,2 \% pytanych jest ona „praktycznym narzędziem wspomagającym ujednolicenie systemu edukacji akademickiej". Zarazem procedura uznawania efektów kształcenia powinna zdaniem połowy badanych dotyczyć 
„tylko edukacji formalnej (szkolnej i uniwersyteckiej)” (49,4\%). Sam temat walidacji i akredytacji dotychczasowych, wcześniejszych osiągnięć edukacyjnych jest także przez połowę puli badanych (50,5\%) uznany za „manewr czysto formalny, który nie poprawi jakości kształcenia i ciągłości pomiędzy kompetencjami absolwentów oraz potrzebami rynku pracy", a zaledwie $8 \%$ uważa go za „interesujący $i$ istotny dla rozwoju edukacji oraz dostosowywania jej do potrzeb rynku pracy w Polsce". Około $30 \%$ uważa zagadnienie za istotne, ale trudne lub niemożliwe do realizacji w polskich warunkach. 45,7\% spośród respondentów, zapytanych o znajomość wybranych terminów z zakresu kształcenia ustawicznego, przyznaje, że ich nie zna, ale domyśla się ich znaczenia (terminy takie, jak sieciowanie sieci, inkubatorium lub imprezy satelitarne). Tylko niecałe $6 \%$ osób zna te terminy, a 37,2\% w ogóle się z nimi nie zetknęło.

Ostatnie zagadnienie, związane z kontekstem tytułowych kompetencji nauczycieli języków obcych, koreluje z dwoma pytaniami ankiety na temat problemu z przystosowaniem kształcenia wyższego w realiach polskich do wymogów stawianych przez reformę oraz znaczeniem kompetencji $w$ tym procesie. Ponownie, zdecydowana połowa ankietowanych, bo 53,1\% uważa, że problem leży w „niekompatybilności formalnych sformułowań i terminologii wobec praktyk dydaktycznych”. Spora część (34\%) wskazała też na „niechęć kadry akademickiej do poddawania się ujednoliconej metodologii pracy oraz powtarzalnym treściom". Są to prawdopodobnie dwa zasadnicze powody, dla których reforma jest uważana za skazaną na niepowodzenie przez większość badanych. Zapytani natomiast o opinię na temat kondycji szeroko opracowywanych i rozbudowywanych kompetencji nauczycielskich w ostatniej dekadzie, w ilości $42,5 \%$ odpowiedzieli, że „opracowania teoretyczne istnieją obok praktyki, gdyż odbiegają od rzeczywistości szkolno-akademickiej (utrudnienia infrastrukturalne, finansowe)". Po ok. $20 \%$ respondentów wskazało na rozmijanie się teorii z praktyką ze względu na „ich - nauczycieli - psychologiczny opór przed zmianą i łamaniem dawnych nawyków metodologicznych”, oraz na „brak czasu kadry akademickiej do dokształcania się i podążania za zmianami paradygmatycznymi". Najmniejszy odsetek osób, wskazujący na zaledwie 25 spośród 188 badanych stwierdził, że teoretyczny opis kompetencji w źródłach naukowych „pokrywa się coraz bardziej z uniwersytecką praktyką dydaktyczną nauczycieli języków obcych (tj. rosną ich kompetencje przedmiotowe oraz kluczowe)".

\section{Wnioski}

Przedstawione wyniki należy potraktować jako narzędzie autorefleksji i przyznać, że opinii środowiska neofilologicznego nie znamionuje optymizm, a wręcz jest 
ona zdecydowanie krytyczna wobec wdrażanych elementów reformy szkolnictwa wyższego. Jest to reakcja zrozumiała, gdyż każda zmiana niesie w pierwszej kolejności jej kontestację, o ile burzy zastany porządek. ${ }^{4}$ Jak obrazują wyniki badania, reforma szkolnictwa wyższego stanowi w opinii badanych cios w tradycję i jakość, do jakiej przywykliśmy. Warto może jednak spojrzeć na posunięcia, które czynione są w innych krajach na rzecz akceptacji negatywnych aspektów demokratyzacji edukacji (umasowienie i spadek jakości) i strategicznie rozważyć możliwe pozytywne efekty dla przyszłych pokoleń studentów. Omawiane badanie pozwala stwierdzić, że respondenci nie upatrują w omawianych poczynaniach administracyjnych teoretycznej możliwości rozwoju kompetencji transpozycyjnych, chociaż przejawiają w związku z nimi kompetencje krytyczne. Kontestacja to cecha pierwszej fazy krytyki destrukcyjnej, która mogłaby przechodzić, dzięki wymienianym wyżej kompetencjom, w krytykę emancypacyjnodziałaniową. Nie oznacza to bezmyślnej akceptacji wszystkiego. Może jednak oznaczać próbę rekonstrukcji rzeczywistości, zwłaszcza dzięki kompetencjom organizacyjnym, realizacyjnym i autokreacyjnym. Do tego potrzeba zatem poszerzenia wachlarza kompetencji w programach kształcenia nauczycieli z li tylko tych, które istotne są w kształceniu językowym o te, które związane są z szerszymi aspektami ustawicznego uczenia się.

\section{BIBLIOGRAFIA}

Arends, R. J. 1994. Uczymy się nauczać. tłum. K. Kruszewski. Warszawa: WSiP.

Banach, C. 2005. « Nauczyciel wobec reformy systemu edukacji ». (w) Nowe w Szkole, $\mathrm{Nr}$ 7-8. 83-84. Dostępne na: http://scholaris.pl.

Czerepaniak-Walczak, M. 1995. Między dostosowaniem a zmianq. Szczecin: Wydawnictwo Naukowe Uniwersytetu Szczecińskiego.

Dylak, S. 1995. Wizualizacja kształtowania nauczycieli. Poznań: Wyd. UAM.

Fullan, M. 1993. "The complexity of the change process ». (w) Change forces: Probing the depth of educational reform, pp. 19-41. Falmer Press. Dostępne na: http://www.personal.psu.edu/wxh139/Fullan.htm DW 10.08.2012.

Goźlińska, E. i Szlosek, F. 1997. Podręczny słownik nauczyciela kształcenia zawodowego. Radom: ITeE.

Jaroszewska, A. 2008. « Analiza kompetencji nauczycieli języków obcych w kontekście nauczania w różnych grupach wiekowych ». (w) Nauczyciel języków obcych dziś i jutro. (red. M. Pawlak, A. Mystkowska-Wiertelak i A. Pietrzykowska). Poznań-Kalisz: WPA UAM: 83-96.

\footnotetext{
${ }^{4}$ M. Fullan, 1993. "The complexity of the change process". (w) Change forces: Probing the depth of educational reform, pp. 19-41. Falmer Press. Dostępne na: http://www. personal.psu.edu/wxh139/Fullan.htm DW 10.08.2012.
} 
Kacprzak, L. 2006. Pedeutologiczne rozważania o nauczycielu. Piła: Wyd. PWSZ. Kupisiewicz, Cz. 2005. Podstawy dydaktyki. Warszawa: WSiP.

Lange, O. 1965. Ekonomia polityczna. Warszawa: PWN.

Męczkowska-Christiansen, A. 2002. Od świadomości nauczyciela do konstrukcji świata społecznego : nauczycielskie koncepcje wymagań dydaktycznych a problem rekonstrukcyjnej kompetencji ucznia. Kraków: Oficyna Wydawnicza „Impuls”.

Mohamedbhai, G. 2012. Internationalization and Global Responsibility, referat wygłoszony na konferencji British Council: Going Global 2012, May 14, 2012. Dostępne na: http://www.insidehighered.com/blogs/world-view/internationalizationand-global-responsibility\#ixzz2B5dLZ9wJ DW 2.11.2012.

Mohamedbhai, G. 2008. The Effects of Massification on Higher Education in Africa. Association of African Universities.

Pfeiffer, W. 2001. Nauka języków obcych. Od praktyki do praktyki. Poznań: Wagros. Raport na temat polityki edukacyjnej w Polsce. OECD. 1995. W-wa: WSiP.

Ryan, T. G. 2007. The Reflexive Classroom Manager: A Required Pre-Service Mode Networks: Vol. 9, Issue 1.

Stach, K. 2002. « Kompetencje zawodowe nauczyciela - spojrzenie na problem ». (w) Kompetencje nauczyciela wychowawcy (red. K. Ferenz i E. Kozioł). Zielona Góra: Oficyna Wydawnicza Uniwersytetu Zielonogórskiego. 19.

Śliwerski, B. 2010. "Inkontrologia pedagogiczna, czyli o wartości spotkania ». http://sliwerski-pedagog.blogspot.com/2010/04/inkontrologiapedagogiczna-czyli-o.html DW 2.11.2012

Zawadzka, E. 2004. Nauczyciele języków obcych w dobie przemian. Kraków: Oficyna Wydawnicza „Impuls”. 